\title{
The Differentiation of Improved Communication Mathematic and Disposition Skill Through Problem Based Learning and Realistic Mathematic Education
}

\author{
Ismail Pasaribu ${ }^{1}$, P. Siagian ${ }^{2}$, Zul Amry ${ }^{3}$ \\ ${ }^{1}$ (Postgraduate, State University of Medan, UNIMED) \\ ${ }^{2,3}$ (Lecturer, State University of Medan, UNIMED)
}

\begin{abstract}
This research aims to describe the differentiation of improved communication and dispositon through Problem Based Learning (PBM) and Realistic Mathematic Education (PMR). This type of research is the quasi experiment school research. The subject of research is the students of grade VIII as many as 28 student. The result of this research that there is a difference in improving students' mathematical communication and disposition through PBM with PMR. Showing students' responses to PBM is better than PMR.
\end{abstract}

Keywords - improving, mathematical communication, disposition skill.

\section{INTRODUCTION}

UNESCO in Mulyasa [1] about the basic of foundation in the world of education, namely: (1) education through four pillars (learning to know, learning to do, learning to live together, learning to be); (2) long-life learning. The efforts to improve the education quality by the government in form of renewal of the curriculum 2013, which mean focus on the character. The purpose of mathematics learning upon curriculum 2013 according to BSNP, Wardhani [2] such that students have the ability to understand concepts, compile evidence communicate mathematical ideas and resilience and confidence in problem-solving. Curriculum 2013 mandates that the process with a saintific approach.

Communicating student ideas/experiences is one of the essentials of mathematics learning. Baroody [3] mentions the reason for the importance of communication in mathematics as a language, not only a tool to aid thinking, and tools to communicate ideas carefully. The importance of communication is stated NCTM [4] that communication is an essential building of mathematical. Silver, et al (NCTM) states that the communication between students and teachers as a responsible together on learning. Furthermore, NCTM [5] related mathematical communication standards include a) mathematical thinking through communication; b) communicate mathematical thinking of students coherently; c) analyze and evaluate the mathematical thinking and strategies used by others; d) using mathematical language to express mathematical ideas correctly. Communication is very important in the life of students both at school and outside of school. The standards of communication focus on the importance of conveying ideas through speaking, writing, drawing and explaining mathematical concepts. Umar [6] that mathematical communication needs to be grown because it is one of the essential of mathematics learning.

The facts in the field, the learning process in the classroom has not been able to improve the ability of mathematical communication. When the students asked to give ideas about a mathematical material, the students look scared and lazy. The first observation conducted to students Junior High School Prayatna Medan. There were 41 students who took the test. Only 8 students can completely finish. Analysis: The student's answer shown the mathematical idea into an arrow diagram has not been true. The student's answer do not matching regards to question. Students' answer do not match regard to writing in the symbol. Unable to write down information that is fully known, it means the deficiency of writing in mathematic. Students can not sketch/shape the diagram properly. Students can not read the questions presented with pictures. Students can not write the full information that is known from the problem. Students do not understand the problem, so they can not get it right. The result of the student's answer can not read the picture. This is one indicator of mathematical communication ability, so it can not express the area of the park. Many factors make low mathematical communication ability. One of them is influenced by the students themselves.

Mahmudi [7] mentions, mathematical dispositions as a success supporting factor to survive facing good problems in mathematics. Good attitude and habits of thinking will form mathematical disposition. In fact, students are still seen tend to be lazy to learn math. First observation and interview of mathematics teacher at Prayatna Junior High School of Medan, Ibu Srimariati on September 10, 2016. She explained that students look lack of enthusiasm in learning mathematics even though the teacher presents with interesting, form study group, find the concept of math. When viewed from other factors in the learning of mathematics that is the conventional method that leads to passive students because it is dominated by teachers. Students only record the main idea. Students could be said to learn actively if there is mobility, visible interaction between teacher and student. the mathematics learning wishes that the students are expected to be active. The concept will be easy to understand if presented through an interesting procedure. According to the importance of mathematical ability and mathematical disposition, teachers should seek innovative learning. Mulyasa said theme of the 2013 curriculum is to produce productive, creative, innovative, 
effective integrated Indonesian human beings. Teachers can choose an approach, strategy or learning model that can involve students actively. So that it would be stick in memory. Learning models designed according to constructivism view. Aims to help students to build math concepts and principles through the process of assimilation and accommodation.

Sagala [8] in the constructivism perspective, students' strategy gain and memorize knowledge. Teacher's job is to facilitate the process is PBM. Deslile [9] states "problem based learning helps raise the quality of education, with PBL strategies, teachers make the shift to higher standards and greater performance ". Arends [10] the emphasis is on presenting authentic and meaningful ideas and demonstrating skills. The PBM procedure focuses on the teacher presenting the problem to the students to investigate the solution. The role of the teacher only as a facilitator in an authentic problem. PBM requires active students to generate confidence. PBM combined with Curriculum 2013. So that can develop the ability to mathematical communication. PMR has good expectations for improving students' mathematical communication and disposition skills. PMR is known as realistic mathematics education implemented in Netherlands less than 30 years. Teffers [11] reveals that $75 \%$ of schools in the Netherlands have used realistic mathematics. Study team MKPBM [12] revealed that students in PMR had higher scores compared to conventional approaches in numeracy skills. The orientation of PMR is: reinvention, the introduction of concepts through concrete issues or around the student's environment.

The hypothesis of this research are: there is difference the improvement of students' mathematical communication taught between PBM with PMR. There is an increased difference in disposition of students between students who are given PBM with PMR.

\section{LITERATURE}

\section{A. Communication Mathematics Ability}

Ansari [13] describes the understanding of mathematical communication mainly consists of mathematical communication spoken and written. Mathematical's spoken communication can be interpreted as an event of interaction (dialog) that occurs in a classroom or small group environment, and there is a transfer of messages containing about the mathematical material being studied Either between teachers with students and among students themselves. While mathematical's written communication is the ability or skill of students using his vocabulary, notation, and mathematical structure either in the form of reasoning, connection or problem solving. Baroody in Ansari also explains that there are two important reasons why communication in mathematics needs to be nurtured among students. First, mathematics as language, meaning mathematics is not just a tool of thinking, mathematics is not only a tool for finding patterns, solving problems or drawing conclusions but also as a valuable tool for clearly communicating ideas, precise and careful. Second, mathematics learning as social activity: mathematics as a social activity in learning, mathematics as well as a vehicle for interaction between students, as well as communication between teachers and students. This is the most important part to accelerate students' math understanding.
Asikin in Rahayu [14] that the role of communication in learning mathematics is: (1) with the communication of mathematical ideas can be exploited in various perspectives, help sharpen students 'thinking and sharpen students' ability in looking at various interrelations of mathematical material, (2) communication is a tool for "measuring" the growth of understanding and reflects students' math understanding (3) through communication, students can organize and consolidate their mathematical thinking, (4) communication among students in learning mathematics is essential for the construction of mathematical knowledge, the development of problem solving and the increase of reasoning, foster selfesteem, and social skills improvement, (5) "writing and talking" can make a very powerful tool for forming an inclusive mathematical community.

\section{B. Mathematics Disposition}

According to NCTM mathematical dispositions encompasses the braving to take risks and exploring diverse problem solutions, persistence to solve challenging problems, taking responsibility for reflecting on the work, appreciating the communication power of the math language, the willingness to ask questions and proposing other mathematical ideas, the willingness to try different ways to explore mathematical concepts, have confidence towards abilities, and view problems as challenges. NCTM, The mathematical disposition contains seven components. The components are: (1) Confidence in using mathematics, (2) Flexible in using mathematics (math), (3) Perseverance in doing math tasks, (4) Full has curiosity in math, (5) Reflecting on the way of thinking, (6) Appreciating the application of mathematics, and (7) Appreciating the role of mathematics.

\section{C. $P B M$ and PMR}

Arends that the essence of PBM is an authentic problematic situation for investigation. Dewey in Trianto [15] PBM is the interaction between stimulus and response, a two-way relationship between learning and the environment. Students' experience gained from the environment becomes the learning material. PBM focuses on directing students to be independent learners in groups. Assist students in thinking to find out an authentic problem solution. Arends suggests that PBM is designed to help students develop thinking skills through a variety of situations. The PMR was developed by Frudental [16] and Streefland [17] on mathematics connected reality, mathematics as a human activity and more focused on the substitute of mechanical learning mathematics to be realistic. Gravemeijer [18] says that mathematics should be cultivated close to the student and must be linked to everyday life. Students are given the opportunity to do the mathematization.

\section{METHODOLOGY}

This research is a quasi-experimental research (quasiexperiment). Control of all external variables that influence the course of research. Grouping of experimental classes 1 and 2 is done based on pre-established groups. Treatment is PBM and PMR, while the observed variables are mathematical communication ability and mathematical disposition of 
students. Locations at SMP Prayatna Medankelas VIII which is done in the first semester of 2017/2018 academic year. The population in this study is all students of Prayatna Junior High School Medan. Based on the consideration that many of the subject matter of SMP mathematics is more interesting.

The following research procedures: Preparation Stage: a) situations that result in mathematical communication ability and mathematical disposition of low students. b) develop research instruments. Implementation Stage: PBM and PMR: a) carry out the pre-test, b) implement the PBM for E-1 and PMR for E-2 classes. c) implement the postest. Data Analysis and Report Writing Stage: by comparing the results between the PBM and the PMR groups. Testing better and drawing conclusions for reports.

TABLE 1 Research Design

\begin{tabular}{|c|c|c|c|}
\hline Group & Pretest & Treatment & Posttest \\
\hline E-1 (Experimen 1) & $\mathrm{T}_{1}$ & PBM & $\mathrm{T}_{2}$ \\
\hline E-2 (Experimen 2) & $\mathrm{T}_{1}$ & PMR & $\mathrm{T}_{2}$ \\
\hline
\end{tabular}

Based on Table 1, T1 = T2: Test the ability of mathematical communication and questionnaire mathematical disposition of students. Treatment by applying PBM and PMR.

\section{RESULT}

Indicates that a significant pretest of mathematical communication skill of experiment class 1 is 0,200 and class of experiment 2 is 0,139 where $0,200>\alpha: 0.05$ and $0,139>\alpha$ : 0.05. So H_0 accepted $H \_1$ denied. Thus the data pretest students' mathematical communication normally distributed. The posttest result of mathematical communication ability of the student of E1 and E2 equal to 0,200 and 0,090, so have a value of $\mathrm{Sig}>0.05$. Then $\mathrm{H} 0$ accepted $\mathrm{H} 1$ rejected. Thus data posttest the mathematical communications to be normally distributed. Significant results of pretest mathematical communication skills in both experimental classes of 0.616 where $0.171>\alpha: 0.05$. So $\mathrm{H} 0$ accepted $\mathrm{H} 1$ is rejected. The linear regression model $\mathrm{Y}$ over $\mathrm{X}$ for the $\mathrm{PBM}$ group is $\mathrm{YE} 1=$ $\mathrm{a} 1+\mathrm{a} 2 \mathrm{XE1}$ with $\mathrm{a} 1$ and $\mathrm{b} 2$ is the estimator for and in the equation $\mathrm{Y}=+\mathrm{XE1}$. The linear regression model $\mathrm{Y}$ over $\mathrm{X}$ for the PMR group is YE2 = a3 + a4 XE2, with a3 and a4 being the estimator for and in the equation $\mathrm{Y}=+\mathrm{XE2}$. ANACOVA or F test, for mathematical communication of PBM and PMR obtained for mathematical communication $\mathrm{F}=11,173$ based on table $\mathrm{F}$, for $=5 \%$ by $\mathrm{F}(1-\alpha ; 1, \mathrm{n}-2)=\mathrm{F}(0.95,1.70)=3.98$. Since $F>F(0.95,1.70)$ and probability $(0.001)$ are less than 0.05 then $\mathrm{H} 0$ is rejected and accepted by $\mathrm{H} 1$. This means that the two linear regression models are not the same or significantly different.

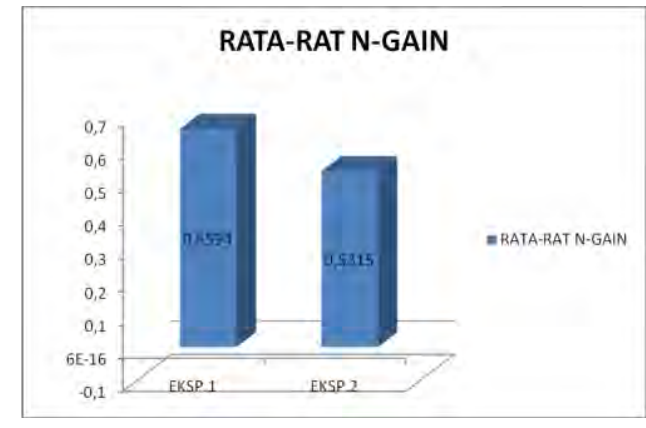

Fig 1. Rata-rat N-gain

Based on figure 1 about Improved descriptions there are a different minimum and maximum n-gain values in both classes. The E1, the minimum and maximum n-gain values were 31 and 48, where as in the E2 the minimum and maximum n-gain values were 21 and 48 . The average value of n-gain test results of students' mathematical communication in the E1 higher than E2 that is 0,6594 and 0,5315 , so there is a difference of improvement of student's mathematical communication in E1 and E2 equal to 0,12. Students' mathematical disposition, In the questionnaire item number 1 positive statement, there are $83.33 \%$ of students strongly agree, $16.67 \%$ of students agree, $0 \%$ of students disagree, and $0 \%$ of students strongly disagree. For questionnaire number 4 with positive statements, there are $66.67 \%$ of students strongly agree, $27.77 \%$ of students agree, $5.56 \%$ of students disagree, and $0 \%$ of students strongly disagree. While the number 13 questionnaires with negative statement, there are $0 \%$ of students strongly agree, $2.7 \%$ of students agree, $30.56 \%$ of students disagree and $66.67 \%$ strongly disagree. Thus more students choose to believe in using math.

Percentage of students' mathematical disposition this positive response is also seen from the description given from the data. This can be seen from the student's reply to the statements given. Indicators giving encouragement to students in the learning process were given through positive questionnaire statement number 1 "finding new ideas", 26 students $(72.2 \%)$ strongly agree, 9 students $(27.1 \%)$ agreed and 1 student $(2.7 \%)$ states disagreed and 0 students $(0 \%)$ stated strongly disagree That means there are 26 students $(72,2 \%)$ likes to find new ideas on learning that tested because more improve student activeness than previous learning. Furthermore, the negative response is also seen from the "motivating" indicator given through the statement number 2, ie 0 students $(0 \%)$ strongly agree, 0 students $(0 \%)$ agreed and 14 students $(38.9 \%)$ stated not 22 students, $1 \%)$ stated strongly disagree This means there are 22 students $(61,1 \%)$ motivated on tested learning because it further improve student communication ability compared to previous learning. 


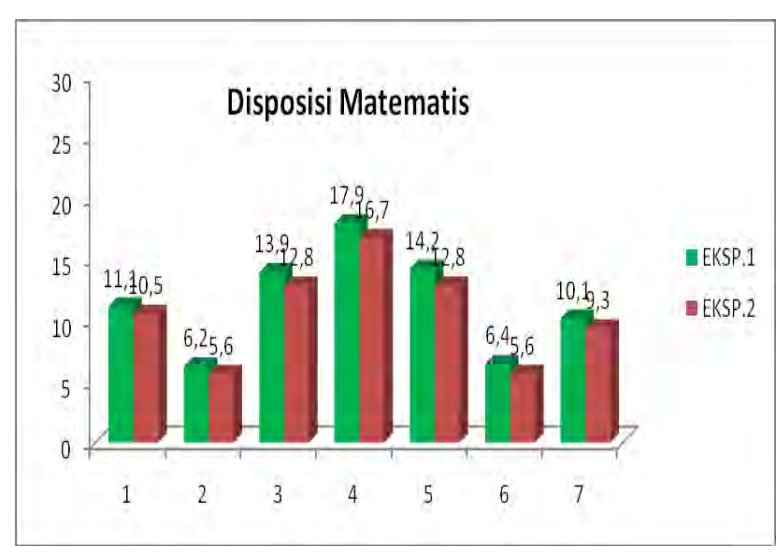

Fig 2. Students' mathematical disposition

Positive responseon on figure 2 is seen from the student's reply to the statements given. Indicators giving encouragement to students in the learning process were given through positive questionnaire statement number 1 "finding new ideas", 26 students $(72.2 \%)$ strongly agree, 10 students $(27.1 \%)$ agreed and 1 student $(2.7 \%)$ expressed no embodiment 0 students $(0 \%)$ stated strongly disagree. That is there are 26 students $(72,2 \%)$ like to find new ideas on learning which tested because more improve student activity than previous learning. Furthermore, negative response is also seen from the indicator "motivate" given through the statement number 2 , ie 0 students $(0 \%)$ strongly agree, 0 students $(0 \%)$ agreed and 15 students (41.7\%) stated not embodied 21 students (58, 3\%) stated strongly disagree This means that there are 21 students $(58,3 \%)$ motivated on tested learning because more improve student communication compared to previous learning.

PBM and PMR in learning is a teacher acts as a facilitator conveying learning objectives, explaining the required logistics and basic competencies that each student must achieve. The function of teachers as facilitators is that teachers give students the freedom to develop their skills presented in the activity. The average posttest that was given PBM was 39.22 higher than PMR of 35.47. The results of this study indicate that the average posttest of mathematical communication which is PBM is higher than PMR. Then by doing covariance analysis resulted in the conclusion that there are the difference of mathematical communication taught PBM with PMR. This difference can be a reference to decision making that mathematical communication in PBM is higher than PMR. The application of PMR has been studied by Saragih [19] on the students of junior high school N6 and junior high school N27 Medan found that of logical thinking and communication of mathematics of junior high school students taught by PMR was better than that owned by junior high school students who taught with the regular way.

Mathematical disposition is the relationship and appreciation of mathematics is a tendency to think and act in a positive way. In this study, in the PBM as many as 14 from 36 students ( $38.9 \%$ )of high disposition and 20 from 36 students $(55.6 \%)$ moderate and low disposition $(5.5 \%)$. While on the PMR disposition students as many as 8 from 36 students $(22.2 \%)$ high and 20 from 36 students $(55.6 \%)$ moderate and low disposition (22.2\%). Based on the results of analysis data, there is a difference in improving students' mathematical communication through PBM with PMR. Showing students' responses to problem-based learning is better than realistic mathematics learning.

\section{ACKNOWLEDGEMENT}

Based on the results of the research, the discussions and conclusions that have been presented can be suggested that the ability of communication mathematic is recommended that should be focus on activity high order thinking.

\section{References}

[1] Mulyasa, Pengembangan dan Impelmentasi Kurikulum 2013 (Bandung: PT Remaja Rosda Karya, 2013).

[2] Wardhani, Analisis SI dan SKL Mata Pelajaran Matematika SMP/MTs untuk Optimalisasi Tujuan Mata Pelajaran Matematika. (Yogyakarta: PPPPTK Matematika, 2008).

[3] Baroody, A.J. Problem Solving, Reasoning, and Kominicating, k-8. Healping Children Thing Mathematically (New York : Merril, an Inprint of Macmillan Publishing, Company, 1993).

[4] NCTM. (1998). Curriculum and Evaluation Standards for School Mathematics. [Online]. http://www.nctm.org/focalpoints. [3S September 2016]. and

[5] NCTM. (2003). Program for Initial Preperation of Mathematics Specialists.

http://www.ncate.org/ProgramStandars/NCTM/NCTMELEMStandars. pdf. [28 April 2016].

[6] Mahmudi, A. Tinjauan Asosiasi antara Kemampuan Pemecahan Masalah Matematis dan Disposisi Matematis. Makalah Disajikan Pada Seminar Nasional Pendidikan Matematika Diselenggarakan oleh Himpunan Mahasiswa Jurusan Pendidikan Matematika FMIPA Universitas Negeri Yogyakarta Yogyakarta, 17 April 2010. Yogyakarta: Universitas Negeri Yogyakarta.

[7] Sagala, S. Konsep dan Makna Pembelajaran (Bandung: Alfabeta, 2010).

[8] Arends, R. I. Learning to Teach. Buku Dua. Edisi Ketujuh (Yogyakarta: Pustaka Pelajar, 2008).

[9] Ansari, B. I. Konsep dan Aplikasi Matematik (Banda Aceh: Yayasan Pena Banda Aceh Divisi Penerbitan, 2012).

[10] Gravemeijer. K.P.E. Developing Realistics Mathematics Educations (Utrecht:CD- $\beta$ Press. Fryudenthal Institute, 1994).

[11] Freundenthal, H. Revisiting Mathematics Education. China Lectures (Dordrecht: Kluwer, 1991).

[12] Saragih, S. (2007). Mengembangkan Kemampuan Berpikir Logis dan Komunikasi Matematis Siswa Sekolah Menengah pertama melalui Pendekatan Matematika Realistik. Disertasi pada Sekolah Pascasarjana UPI: Tidak Diterbitkan.

[13] Trianto. (2011). Model Pembelajaran Terpadu Konsep, Strategi dan Implementasinya Dalam Kurikulum Tingkat Satuan Pendidikan (KTSP). Jakarta: Bumi Aksara.

[14] Streefland, L. (1991). Realistics Matematics Education in Primary School. Urect:Frudenthal Institute.

[15] Wijaya, A. (2012). Realistic Mathematics Education: An Alternative Approach to Mathematics Learning. Yogyakarta: Graha Ilmu.

[16] Arikunto, B.I. (2009). Dasar-dasar Evaluasi Pendidikan. Jakarta: Bumi Aksara.

[17] De Lange, J. (1996). Using and Appliying Mathematics In Education. In A.J. Bishop (Ed). International Handbook of Mathematics Education. Dordrecnt: Kluwor Academics Publisher,

[18] Hulukati, E. (2005). Mengembangkan Kemampuan Komunikasi dan Pemecahan Masalah Matematik Siswa SMP melalui Model Pembelajaran Generatif. Bandung: Disertasi PPs UPI. Tidak diterbitkan. 
[19] Lindquist, M.M dan Elliott, P.S. (1996). "Communication an Imperactive for Change: A Conversation with Mary Lindquist". Communication in Mathematics K-12 and Beyond. Virginia: NCTM.

[20] Mandur, K. dkk. (2013). Kontribusi Kemampuan Koneksi, Kemampuan Reprentasi, dan Disposisi Matematis terhadap Prestasi Belajar Matematika Siswa SMA Swasta di Kabupaten Manggarai. E-Journal PPs Universitas Pendidikan Ganesha. Vol. 2. Thn. 2013. Halaman:2.

[21] Netter, J. (2005). Applied Linear Statistical Models. IIIions : Richard D. Erwin, INC.
[22] Slavin R. (1997). Cooperative Learning.Second Edition. Allyn \& Bacon. A Simon \& Aschuster Company.

[23] Sudjana. (2005). Metode Statistika. Bandung: Tarsito

[24] Syaban, M. (2009). Menumbuhkembangkan Daya dan Disposisi Matematis Siswa Sekolah Menengah Atas Melalui Pembelajaran Investigasi. Educationist. Vol. III No. 2. Halaman: 113.

[25] Turmudi. (2008). Landasan Filsafat dan Teori Pembelajaran Matematika (Berparadigma Eksploratif dan Investigatif). Jakarta: Leuser Cipta Pustaka 